\section{Non-Proliferation Treaty woes}

SIR - Your leading article (Nature 8 March, p.97) makes some telling points on the finer nuances of international nuclear politics. I should like to comment on one of the issues you raise: that of the imminent danger of the collapse of the Non-Proliferation Treaty (NPT).

There seem to be two contentious issues that the current nuclear weapons states refuse to address seriously. First, Article VI of the NPT requires them to "pursue negotiations in good faith on effective measures relating to cessation of the nuclear arms race". There is scant evidence that any of the nuclear weapons powers is doing any such thing.

Second, at least two of the current nuclear weapons states - Britain and the United States - reserve the right under the "safeguards" agreements signed with the International Atomic Energy Agency (IAEA) in 1978 and 1979 respectively to withdraw special nuclear materials from the civilian stockpile for military purposes if so deemed necessary by "supreme national security" considerations.

Indeed, Dr Charles F. Gilbert, then acting Deputy Assistant Secretary for Nuclear Materials at the US Department of Energy, told a congressional committee in 1981 that the attempt to amend the US Nuclear Waste Bill by Senators Hart and Simpson, which would prohibit the "mining" of plutonium produced in civil nuclear reactors for military purposes, was not supported by the US administration. Gilbert said that the Hart-Simpson amendment would "restrict our ability to obtain plutonium and might have serious consequences if the United States should need additional (military) plutonium".

Events since have shown the US administration is indeed planning a nuclear weapons programme expansion that will demand a considerable build-up of its fissile material stockpile for warhead manufacture. In 1982, Dr Herman E. Roser, Assistant Secretary of Defense Programs, US Department of Energy, told a congressional hearing that, with regard to the possible diverting of civilian plutonium to the US defence programme, "I do not believe we should foreclose that option because I don't think we should foreclose any options, when it comes to the security of this country". Yet Deborah Shapley reported (Nature 297, 255; 1982) "Critics of DoE's plans argue that if the United States starts taking civilian spent fuel from its weapons programme, it will not have a leg to stand on when it tries to dissuade other countries likewise".

This criticism applies equally to the United Kingdom Government. Article 14 of its "safeguard" agreement with IAEA and Euratom states that the British Government may withdraw special nuclear materials from the scope of the agreement for "national security reasons". Although the British Government states it has no intention of exercising this right, it continues to reserve the right legitimately to divert civil nuclear materials for military purposes, if circumstances of dire national security demand so.

Nature's proper worry that the NPT may collapse at the 1985 Review Conference is certainly justified. The 1980 Review Conference only narrowly avoided such a fate. Events since then have exacerbated the situation, with suggestions that Argentina and Pakistan (Note 10) both nonsignatories to the NPT, now have facilities to make their own nuclear weapons.

The 1985 NPT Review Conference offers a real chance for a resurrection of trust and confidence between nations. It seems the nuclear weapons states must show willingness to take the first positive steps if the conference is to avoid disaster. The scientific community surely have a duty to help make sure this disaster does not occur.

DAVIDLOWRY

Energy Research Group,

The Open University,

Milton Keyns MK7 6AA, UK

\section{Plagiarism in texts}

SIR - It is difficult to see how any text book can be written without some kind of plagiarism since there can rarely be a scientist who can fill a book with the results of his own researches. Authors of larger text books are usually academics busy with lectures, research and administration and generally delegate the work to secretaries who are asked to rewrite such and such a piece incorporating a few additional pieces of recent research. The stage is not set for convergent evolution, so why not accept the fact? BRENNIG JAMES

The Doctors' House,

Claremont Road, Marlow, Bucks, UK

\section{Citations overlooked}

SIR - In my review of John Nicholson's Men and Women (Nature 307, 764; 1984) I wrote that the author "rarely cites primary sources". This remark may have been misleading, since although he rarely cites them in the text, he does quote some primary sources (together with secondary ones) at the back of the book. Although each reference includes the page number to which it refers, it would take a very diligent reader to connect the references with the text, since the references for each chapter are arranged in alphabetical order, not in the order of the pages to which they relate.

\section{Centre for Research on} STUART SUTHERLAND

Perception and Cognition,

University of Sussex,

Brighton BN1 9QG, UK

\section{Inviable usage}

SIR - The Shorter Oxford English Dictionary defines the word "viable" as, inter alia, "able to maintain a separate existence" and, pace Dr Gill (Nature 307, $312 ; 1984)$, it is in this sense that it is usually used in embryology and neonatology. A "viable" unborn child is, in fact, one that is capable of surviving if separated from its mother, when incidentally its life is protected under the Infant Life (Preservation) Act 1929.

A fetus which can in no circumstances survive apart from the mother, when for example its lungs are not yet capable of being inflated, ought not to be described as "viable", even though "in the appropriate environment", that is, in its mother's womb, "it is indeed capable of maintaining its life, given adequate oxygen and nutrition". It is, however, possible, and perhaps useful, to draw a distinction between a fetus which is "previable", meaning that although it is not yet viable it is capable of later becoming so, and one that is "inviable" which, although still alive, can in no circumstances be expected to achieve viability. C. B. GOODHART Gonville and Caius College, Cambridge CBZ ITA, UK

SIR - Your correspondent (Nature 307, $312 ; 1984)$ must have reasons of his own to obfuscate the meaning of "previable". The editors of Butterworths Medical Directory (Butterworths, 1965) do not share his plight, and define the word to mean "before the point at which extra-uterine existence is possible". What can be plainer than that? R.P.S. JANSEN

The Royal Prince Alfred Hospital,

Missenden Road, Camperdown, NSW 2050, Australia

\section{Xiaoping first?}

SIR - First name or last name first? "The Second Nuclear Wars Composite"' (Nature 306, 509; 1983) did little to settle the issue. This case in particular, the Chinese word "xiao" means diminutive and "ping" signifies peace. In a country officially espousing peace, millions of small children are endeared by the nickname Xiaoping, which happens to be Deng's given name. To call him by that is perhaps seventy years too late.

Gerontocratic tradition and authoritative reverence demand all respectable Chinese except those in the inner circle of power to use his full name, Deng Xiaoping. Westerners may be forgiven for calling him Deng, his surname. But to list "Reagan, Brezhnev, Mitterand, Thatcher and Xiaoping"' is almost like saying "Reagan, Mitterand, Thatcher, Deng and Lenya."

RICHARD J. WANG

John M. Dalton Research Center,

University of Missouri,

Research Park,

Columbia, Missouri 65211, USA 